\title{
Correction to: The SAMHD1-mediated block of LINE-1 retroelements is regulated by phosphorylation
}

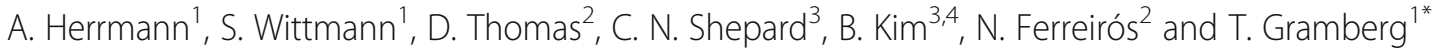

\section{Correction}

The original article [1] contains an omission in the Methods. The authors would like to note that the paragraph constituting the L1 promoter assay should read as the following:

L1 promoter assay

HEK-293T cells were transfected with the L1 promoter luciferase reporter plasmid ( $1_{\mathrm{RP}}$-luc) together with empty vector (pcDNA6mycHis) or SAMHD1 expressing vector using calcium phosphate. The reporter plasmid $\mathrm{L} 1_{\mathrm{RP}}$-luc and the $\mathrm{L} 1$ promoter activity assay have been described previously [2]. Two days posttransfection, cells were lysed with Cell Culture Lysis $5 \times$ reagent (Promega) and luciferase activity was quantified using commercially available components (Promega).

\section{Author details}

${ }^{1}$ Institute of Clinical and Molecular Virology, Friedrich-Alexander University Erlangen-Nürnberg, Schlossgarten 4, 91054 Erlangen, Germany.

${ }^{2}$ pharmazentrum frankfurt/ZAFES, Institute of Clinical Pharmacology, Goethe-University, Theodor Stern Kai 7, 60590 Frankfurt am Main, Germany.

${ }^{3}$ Center for Drug Discovery, Department of Pediatrics, Emory Center for AIDS Research, Emory University, Children's Healthcare of Atlanta, Atlanta, GA

30322, USA. ${ }^{4}$ College of Pharmacy, Kyung-Hee University, Seoul, South Korea.

Published online: 01 May 2018

\section{References}

1. Herrmann A, et al. The SAMHD1-mediated block of LINE-1 retroelements is regulated by phosphorylation. Mob DNA. 2018;9:11.

2. Yu F, Zingler N, Schumann G, Strätling WH. Methyl-CpG-binding protein 2 represses LINE-1 expression and retrotransposition but not Alu transcription. Nucleic Acids Res. 2001;29:4493-501.

\footnotetext{
* Correspondence: thomas.gramberg@fau.de

${ }^{1}$ Institute of Clinical and Molecular Virology, Friedrich-Alexander University

Erlangen-Nürnberg, Schlossgarten 4, 91054 Erlangen, Germany

Full list of author information is available at the end of the article
}

(c) The Author(s). 2018 Open Access This article is distributed under the terms of the Creative Commons Attribution 4.0 International License (http://creativecommons.org/licenses/by/4.0/), which permits unrestricted use, distribution, and reproduction in any medium, provided you give appropriate credit to the original author(s) and the source, provide a link to the Creative Commons license, and indicate if changes were made. The Creative Commons Public Domain Dedication waiver (http://creativecommons.org/publicdomain/zero/1.0/) applies to the data made available in this article, unless otherwise stated. 